\title{
Role of the academic curriculum in the development of the basic learning outcomes (knowledge - skills - capabilities) of the architect using the method of currere
}

\author{
${ }^{1}$ Sajjad Yaqoob Yousif, ${ }^{2}$ Nawfal Josef Rizco \\ ${ }^{1,2}$ Architectural Department, College of Engineering, Al-Nahrain University, Baghdad, Iraq
}

\section{Article Info}

Received Jan 14, 2019

\section{Keyword:}

Academic curriculum

Academic outcome

Architecture

Method of Currere

\begin{abstract}
Basic learning outcomes play an important role in giving students the general academic profile that determines the characteristics of the academic program outcome. The research problem is formulated, which is the lack of clarity about the role of the academic curriculum in the development of the basic learning outcomes of the architect in particular. Based on the foregoing, the research has tackled the development of basic learning outcomes (knowledgeskill-capability) for the architect in particular, using the method of Currere that is approved globally in the development of academic curricula and vocabulary (knowledge - skill - capacity) for the purpose of developing the efficiency of the academic outcome. The research adopted a descriptive analytical method using the method of Currere. The results of the research include a diagnose of a number of gaps which were based on reviewing the vocabulary of the course according to the need for it or its compatibility with the academic description of the graduate engineer or the academic outcome. Furthermore, the research determines some conclusions that showed the shortcomings of the academic curriculum and the reality of the practice, as well as the research has recommended with a set of recommendations that maximize the compatibility between the outcomes of the academic program and the requirements of the labor market.
\end{abstract}

\section{Corresponding Author:}

Sajjad Yaqoob Yousif, Architectural Department, College of Engineering, Al-Nahrain University, Baghdad, Iraq Email: sagaduqup@gmail.com

\section{Introduction}

The rapid and successive changes in the areas of architectural education and its relationship to the labor market in the world in general and in Iraq in particular have influenced the formulation of the academic curriculum with its vocabulary school in general and in all engineering, social competencies and others as well. In view of the foregoing, there was a need to review the academic outcome characterization (architect), which determines the efficiency of its performance in the reality of the practice through the development of the academic curriculum as the basic input of the academic program.

\section{Academic curriculum}

The academic curriculum is a distinguished and organized set of courses that lead to the granting of the academic degree associated with this program (Bachelor, Diploma, Master, etc.) [1]. It is having been also defined by Hameed as the most effective means of learning that provide a translation for philosophies and 
educational policies into a reality fact. Through the academic curriculum, development plans to increase the options available to people to live a life free of ills are supported. Further, to acquire and get the resources to have a decent life, and through the curriculum [2,3]. The Arab Universities Union has defined the curriculum as a distinguished and organized set of courses that lead to the granting of the academic degree associated with this program (Bachelor, Diploma, Master, etc.) [4]. It is a group of educational experiences designed in the framework of planning ahead to achieve educational and educational goals with the intention of helping Learners on the overall growth in all aspects of personality by creating educational and academic institutions within the framework of goals, content, activities and methods of teaching and evaluation [5].

\section{Learning outcomes}

Learning outcomes are the outcome of the learning process, which is delivered to the learner - which the institution wishes to achieve through specific educational activities and knowledge, as well as assessment methods that measure the extent to which these results are achieved [6]. Rizko has also defined it as phrases that describe what the learner should know and able to perform. Students are expected to complete such outcomes at the end of their studies for a specific curriculum or course of study. Learning outcomes are of great importance to all parties involved in the educational process or are the basic information and concepts that the student must acquire when completing the academic program until graduation. [7,8]. In addition, some literary studies have shown several definitions of learning outcomes, such as the study of the student's expected ability to do a work as a result of an educational activity. American Association of Law Libraries has defined it as the knowledge, skills and tendencies acquired as a result of an educational activity. Moreover, it is a practical application of how knowledgeable the learner is or what will be able to do as a result of this activity. They are defined by Adam as what is expected from the students/learners to be able to do as a result of the conclusion of the unit/curriculum or a qualification. It is one of the essential foundation blocks in the transparency of educational systems. Based on the above, we find that learning outcomes are divided into two parts; target learning outcomes, which are the knowledge, skills and abilities that are acquired through the curriculum, and actual learning outcomes, which are actually required in the labor market that is based on the employment of architect [9]. The learning outcomes associated with the architect are divided into the knowledge, skills and capabilities as follows:

\section{3-1 Knowledge}

Knowledge is the basic information and concepts that a student must acquire when completing the academic program until graduation. The elements that characterize the engineer are his knowledge of facts and concepts. Knowledge represents the database of the professional engineer [10,11]. Knowledge is linked to the knowledge material needed by the student according to pure theoretical lessons such as theory and history of architecture, design methodology, building services, and other theoretical lessons such as architectural design lessons, construction of buildings and others [12].

\section{3-2 Skills}

Skills represent the tools used by the architect to invest knowledge in order to accomplish a particular work according to his behavior [13]. These skills are cognitive skills [9]. Professional and practical skills [14] and general skills: [15].

\section{3-3 Capabilities}

Capability is the behavior that will guide knowledge and skills to achieve a specific goal and what this behavior includes such as personal values, attitudes, interests and personal tendencies [13]. Since man is born with certain abilities and talents that vary from one person to another. Therefore, some abilities and talents, some inherent and the other acquired, must be available in the individual to become an architect. The most obvious capabilities and talents of the personality of architectural qualities must be the logical capacity, creative artistic skill, scientific and professional capabilities, and administrative capacity, which affect the professional performance of the architect and meet the requirements of his profession $[16,17]$. 


\section{Architect}

The architect was defined according to French law as a translation of the French word "Architect", which means the professional entrusted with the design, drawings and models for the establishment, maintenance, decoration and supervision of the proper implementation. $[9,18]$. The architect at the linguistic level is a name derived from "yueamar", and at the professional level is determined in three basic pillars: the achievement of the benefit and the building function - the achievement of durability and strength of construction - the beauty of formation [14]. Maamouri has also defined the architect as the person whose ideas and thoughts overlap in the life of every human being on earth; he is the one that form the empty in which the individual lives $[19,20]$.

\section{Method of Currere}

In an article entitled "Method of Currere", Pinar suggests that the method can be addressed through four moments or steps (regressive - progressive - analytical - synthetic) [13]. Method of Currere was first known and defined when the concept of the method of Currere in linguistics in 1970s, when Pinar and other curators developed the term Currere based on the Latin source of the word "curriculum", which means run the course, that is, the management of the course. For "Currere", it means (track-run-trip) . The concept of the method of Currere was conventionally defined by a number of researchers; as it is defined by Pinar as (Currere), is a time self-reflection with a temporal and conceptual nature, and aims to create a developmental perspective over time and between concepts, and from another point of view, what is conceived over time is presented. In the hope of exploring the complex temporal and conceptual relationship through performing that, it is an endless form of curriculum that includes a framework for thinking about the curriculum vitae that ultimately forms the individual's understanding of oneself in our democratic society. Madeleine R. has defined (currere) as a reflective cycle where thought is reflected on itself and thus regains its will, namely, "understanding life by going backwards, living looking forward" [21]. The method of Currere was used to evaluate a number of literary studies from outside the field of architecture. As for the field of architecture, one foreign study for the development of the architectural program for the master stage, entitled "Becoming an Architect: Narratives of Architectural Education," was conducted through the evaluation of the participant (academic outcome) of the program has tackled the same idea. Therefore, the academic program inputs are developed represented in the architectural academic curriculum through four moments (regressive - progressive - analytical - synthetic). Such four moments represent four approaches (Curriculum - narrative approach - Anthrax curriculum participant leadership approach), which are a reflection of the experience of the participant (the academic outcome) in the practical reality of the labor market, through the stories of real or imaginary express the past and future vision of the participant. In addition, they are an analysis of his experience at the present time, and accordingly, through a synthetic process of the previous three moments, the participant gives his vision of coevaluate and develop the architectural academic curriculum, and this is done through the words and the text and its interpretations.

\section{Four Moments/Steps of the Method of Currere}

Method of Currere is a systematic method consisting of four steps or moments that depict temporal and reflective movements in the study of the actual practice in the labor market ((1) regressive, (2) progressive, (3) analytical, and (4) synthetically moment). In the regressive moment, the living individual experience is the data source [22]. In the progressive moment We now turn to the future, reflecting the retrograde echo as "the future of the present in the sense that it is the present of the past, Based on Pinar's idea that the future affects, in complex ways, present and present, to understand the future, one must think of the future at present, because "the future exists in the same sense as the past" $[15,24,25]$. In the analytical moment We have now reached the analytical moment, examining the present through a more reflective exercise. In this step, participants begin to integrate the effects of social, cultural and institutional factors on their current situation [16,27]. In the synthetically moment This moment is the main source of analyzed data. Here, we ask the participants to review the three ideas they have already created during the process, and although this phase is separate from experience, it is still a material experiment $[23,26]$. These four moments and their literary approaches will become the reliable source for us to collect the information of the participants in this study and to present a vision regarding the compatibility of the outputs of the academic program with the requirements of the labor market by reviewing the curriculum vitae of the practicing engineer, What you get from the academic academic program of competence (knowledge, skills and abilities) qualify him to work in 
line with the needs of the labor market, and imagine the future by telling a fictional story about the architectural profession and the relationship of the architect, and analyze the relationship of free to practice with His current career, which represents the third moment of Corrier, and finally the collection of the previous images in one image represents the participant's vision to evaluate the inputs of the academic program (curriculum in its own vocabulary) as a feedback to draw the features of the architect of the future.

\section{Results related to the adoption of the method of currere for the development of the academic curriculum}

Table 1. shows the results from the responses of the participants in the Method of Currere

\begin{tabular}{|c|c|c|c|c|}
\hline \multirow[t]{2}{*}{ Participant } & \multicolumn{4}{|c|}{ Text and its interpretations } \\
\hline & Regressive moment & Progressive moment & Analytical moment & $\begin{array}{l}\text { Synthetically } \\
\text { moment }\end{array}$ \\
\hline \multirow[t]{2}{*}{$\begin{array}{l}\text { First } \\
\text { participant }\end{array}$} & $\begin{array}{l}\text { Most of my time was } \\
\text { devoted to the design }\end{array}$ & \multirow{2}{*}{$\begin{array}{l}\text { In-depth study of } \\
\text { technology and its } \\
\text { relation to architecture are } \\
\text { important axes of the } \\
\text { outlook }\end{array}$} & $\begin{array}{l}\text { Design and } \\
\text { implementation of } \\
\text { commercial houses } \\
\text { and buildings }\end{array}$ & \multirow{2}{*}{$\begin{array}{l}\text { Through previous } \\
\text { moments, I find it } \\
\text { necessary to have a } \\
\text { vision for the } \\
\text { structural aspect so } \\
\text { that the architect } \\
\text { can create new and } \\
\text { unconventional } \\
\text { forms }\end{array}$} \\
\hline & $\begin{array}{l}\text { I had earlier visions } \\
\text { of architecture }\end{array}$ & & $\begin{array}{l}\text { Participate in the } \\
\text { design of a number } \\
\text { of health buildings }\end{array}$ & \\
\hline \multirow[t]{5}{*}{$\begin{array}{l}\text { Second } \\
\text { participant }\end{array}$} & $\begin{array}{l}\text { Painting and } \\
\text { imagination are the } \\
\text { basic requirement for } \\
\text { excellence in the } \\
\text { study of architecture }\end{array}$ & $\begin{array}{l}\text { Architectural competition } \\
\text { based on advanced } \\
\text { technologies, competitive } \\
\text { prices and standard } \\
\text { delivery time }\end{array}$ & \multirow[t]{2}{*}{$\begin{array}{lr}\text { Practitioner } & \\
\text { currently suffers } \\
\text { from lack of } \\
\text { resources and } \\
\text { difficulty } \\
\text { implementation }\end{array}$} & $\begin{array}{l}\text { Practitioner must } \\
\text { understand the } \\
\text { standards and } \\
\text { dynamics of } \\
\text { different buildings }\end{array}$ \\
\hline & $\begin{array}{l}\text { Who did not adapt to } \\
\text { the reality of the } \\
\text { situation had to } \\
\text { postpone the study }\end{array}$ & $\begin{array}{l}\text { Know the technical } \\
\text { aspects of implementation } \\
\text { and design }\end{array}$ & & $\begin{array}{l}\text { The time is not } \\
\text { enough to study } \\
\text { everything about } \\
\text { architecture } \\
\text { (suggested that the } \\
\text { study be seven } \\
\text { years) }\end{array}$ \\
\hline & $\begin{array}{l}\text { Students who had } \\
\text { imagination and love } \\
\text { of architecture } \\
\text { completed the school } \\
\text { years with excellence }\end{array}$ & $\begin{array}{l}\text { There are places } \\
\text { dedicated to horizontal } \\
\text { buildings and other } \\
\text { vertical buildings }\end{array}$ & \multirow[t]{2}{*}{$\begin{array}{l}\text { Lack of advanced } \\
\text { companies in terms } \\
\text { of technology in } \\
\text { the field of } \\
\text { implementation }\end{array}$} & $\begin{array}{l}\text { Specialization for } \\
\text { the study of } \\
\text { architecture is a } \\
\text { necessary } \\
\text { requirement }\end{array}$ \\
\hline & $\begin{array}{l}\text { All my time was } \\
\text { dedicated to design, } \\
\text { painting and show }\end{array}$ & $\begin{array}{l}\text { Adoption of many laws to } \\
\text { protect the architectural } \\
\text { profession }\end{array}$ & & $\begin{array}{l}\text { Study of the } \\
\text { industrial } \\
\text { establishment as a } \\
\text { study unit, } \\
\text { including the } \\
\text { internal design of } \\
\text { the aircraft and } \\
\text { aircraft }\end{array}$ \\
\hline & $\begin{array}{l}\text { I did not have time to } \\
\text { study events and } \\
\text { functions (Ref. }\end{array}$ & $\begin{array}{lr}\begin{array}{l}\text { There is greater } \\
\text { awareness of } \\
\text { community } \\
\text { about } \\
\text { architecture thanks to the } \\
\text { means of social } \\
\text { communication }\end{array}\end{array}$ & $\begin{array}{l}\text { Restriction of the } \\
\text { architect }\end{array}$ & $\begin{array}{l}\text { Allocate time to } \\
\text { visit buildings } \\
\text { under construction } \\
\text { periodically }\end{array}$ \\
\hline
\end{tabular}




\begin{tabular}{|c|c|c|c|c|}
\hline & $\begin{array}{l}\text { I was hoping to learn } \\
\text { more about the } \\
\text { vocabulary of the } \\
\text { other curriculum but } \\
\text { the time was not } \\
\text { enough }\end{array}$ & $\begin{array}{l}\text { There are many buildings } \\
\text { that will be over } 100 \\
\text { years old }\end{array}$ & & $\begin{array}{l}\text { Business } \\
\text { management, } \\
\text { advanced } \\
\text { construction } \\
\text { techniques and } \\
\text { construction } \\
\text { economics of } \\
\text { vocabulary that I } \\
\text { imagine to be a } \\
\text { requirement for the } \\
\text { labor market }\end{array}$ \\
\hline & $\begin{array}{l}\text { The study was } \\
\text { superficial and simple } \\
\text { for some materials }\end{array}$ & $\begin{array}{l}\text { Tourism is the most } \\
\text { important } \\
\text { resource }\end{array}$ & $\begin{array}{lr}\text { I } & \text { was } \\
\text { commissioned } & \text { to } \\
\text { study and design an }\end{array}$ & $\begin{array}{l}\text { Preservation and } \\
\text { rehabilitation of old } \\
\text { buildings }\end{array}$ \\
\hline & $\begin{array}{l}\text { (such as architecture, } \\
\text { environment, lighting, } \\
\text { acoustics, building } \\
\text { systems) }\end{array}$ & & $\begin{array}{l}\text { industrial plant and } \\
\text { did not have a basic } \\
\text { knowledge of this } \\
\text { type }\end{array}$ & $\begin{array}{lr}\text { Attention } & \text { to } \\
\text { creativity } & \text { and } \\
\text { innovation } & \end{array}$ \\
\hline & $\begin{array}{l}\text { The architect must } \\
\text { understand what he } \\
\text { draws }\end{array}$ & & establishment & \\
\hline $\begin{array}{l}\text { Third } \\
\text { participant }\end{array}$ & $\begin{array}{l}\text { My relationship may } \\
\text { not look good with } \\
\text { the architecture } \\
\text { profession in the first } \\
\text { stage. }\end{array}$ & $\begin{array}{l}\text { The most important future } \\
\text { projects are the work on } \\
\text { residential complexes and } \\
\text { the development of old } \\
\text { neighborhoods. }\end{array}$ & $\begin{array}{l}\text { Participate in the } \\
\text { development of the } \\
\text { master plan for ten } \\
\text { cities }\end{array}$ & $\begin{array}{l}\text { RAFT program is } \\
\text { currently the } \\
\text { architect's tool }\end{array}$ \\
\hline & $\begin{array}{l}\text { The design was } \\
\text { difficult to understand } \\
\text { at the same time }\end{array}$ & & & $\begin{array}{lr}\text { Gis } & \text { program } \\
\text { represents } & \text { an } \\
\text { important work tool }\end{array}$ \\
\hline & $\begin{array}{l}\text { Signs of } \\
\text { understanding of the } \\
\text { architectural } \\
\text { profession start in the } \\
\text { second stage }\end{array}$ & & & $\begin{array}{l}\text { in project planning, } \\
\text { housing and urban } \\
\text { projects }\end{array}$ \\
\hline & $\begin{array}{l}\text { The single history of } \\
\text { architecture was an } \\
\text { important one through } \\
\text { which ancient } \\
\text { civilizations were } \\
\text { identified }\end{array}$ & & $\begin{array}{l}\text { The most important } \\
\text { requirements that } \\
\text { the customer has } \\
\text { requested to add a } \\
\text { local touch on the } \\
\text { buildings according }\end{array}$ & $\begin{array}{l}\text { RAFT program is } \\
\text { currently the } \\
\text { architect's tool }\end{array}$ \\
\hline & $\begin{array}{l}\text { The greatest benefit } \\
\text { of this phase was } \\
\text { learning the Max } \\
\text { program (MAX) }\end{array}$ & & $\begin{array}{l}\text { to the city's } \\
\text { specificity }\end{array}$ & \\
\hline $\begin{array}{l}\text { Fourth } \\
\text { participant }\end{array}$ & $\begin{array}{l}\text { The architectural } \\
\text { profession is vague in } \\
\text { the first stage }\end{array}$ & $\begin{array}{l}\text { I am the Director of } \\
\text { Engineering Consulting } \\
\text { Company }\end{array}$ & $\begin{array}{l}\text { I worked on many } \\
\text { investment projects } \\
\text { (hospitals - schools } \\
-\quad \text { university } \\
\text { buildings) }\end{array}$ & $\begin{array}{l}\text { There is weakness } \\
\text { in detailed } \\
\text { drawings } \\
\text { (architectural and } \\
\text { structural) }\end{array}$ \\
\hline & $\begin{array}{l}\text { The second phase was } \\
\text { stressful and useful at } \\
\text { the same time }\end{array}$ & $\begin{array}{l}\text { Needed young graduate } \\
\text { engineers }\end{array}$ & $\begin{array}{l}\text { Worked on external } \\
\text { space designs }\end{array}$ & $\begin{array}{l}\text { There is a weak } \\
\text { regulation of time }\end{array}$ \\
\hline & ambiguity & Some are specialized in & I worked on the & need \\
\hline
\end{tabular}




\begin{tabular}{|c|c|c|c|c|}
\hline & $\begin{array}{l}\text { returned to the } \\
\text { architecture } \\
\text { profession in the third } \\
\text { stage }\end{array}$ & $\begin{array}{l}\text { architectural details with } \\
\text { modern touch and others } \\
\text { specialized in } \\
\text { construction details }\end{array}$ & $\begin{array}{l}\text { development of a } \\
\text { number of religious } \\
\text { buildings, including } \\
\text { Mazar Qasim in the } \\
\text { city of Hilla }\end{array}$ & $\begin{array}{l}\text { cooperation in } \\
\text { work }\end{array}$ \\
\hline & $\begin{array}{l}\text { There are } \\
\text { misconceptions about } \\
\text { the profession of } \\
\text { architecture }\end{array}$ & $\begin{array}{l}\text { Specialists in the work of } \\
\text { the three models }\end{array}$ & $\begin{array}{l}\text { The work has been } \\
\text { provided with all } \\
\text { the requirements of } \\
\text { internal and }\end{array}$ & $\begin{array}{l}\text { Increase interest in } \\
\text { interior designs, } \\
\text { green spaces and } \\
\text { sustainability }\end{array}$ \\
\hline & & & $\begin{array}{l}\text { external binoculars } \\
\text { and external spaces }\end{array}$ & $\begin{array}{l}\text { Local models are } \\
\text { one of the } \\
\text { requirements of the } \\
\text { local labor market }\end{array}$ \\
\hline & $\begin{array}{l}\text { Link building } \\
\text { ocean, hith } \\
\text { society }\end{array}$ & Some are sustainable & $\begin{array}{l}\text { One of the most } \\
\text { important } \\
\text { requirements of the } \\
\text { customer to work } \\
\text { according to local } \\
\text { models }\end{array}$ & $\begin{array}{l}\text { Building buildings } \\
\text { according } \\
\text { modern } \\
\text { technologies }\end{array}$ \\
\hline & $\begin{array}{l}\text { There is a local and } \\
\text { global character of the } \\
\text { buildings }\end{array}$ & $\begin{array}{l}\text { Work integrated projects } \\
\text { with my team regarding } \\
\text { internal and external }\end{array}$ & $\begin{array}{l}\text { Some customers } \\
\text { were asking us to } \\
\text { implement } \quad \text { or }\end{array}$ & $\begin{array}{l}\text { Specialization in } \\
\text { architectural study } \\
\text { so that the student }\end{array}$ \\
\hline & $\begin{array}{l}\text { Structural and } \\
\text { architectural details }\end{array}$ & $\begin{array}{l}\text { design and taking into } \\
\text { account the } \\
\text { environmental aspects. }\end{array}$ & $\begin{array}{l}\text { supervise the } \\
\text { implementation to } \\
\text { be done according }\end{array}$ & $\begin{array}{l}\text { has the time to } \\
\text { learn and train on a } \\
\text { specific thing }\end{array}$ \\
\hline & $\begin{array}{l}\text { Sense } r \\
\text { understanding the } \\
\text { profession through } \\
\text { the fourth stage } \\
\end{array}$ & $\begin{array}{l}\text { How to implement the } \\
\text { building in accordance } \\
\text { with modern building } \\
\text { regulations }\end{array}$ & to the designer & \\
\hline & $\begin{array}{l}\text { My guesswork and } \\
\text { practice had a } \\
\text { distinctive addition to } \\
\text { this stage }\end{array}$ & & & \\
\hline $\begin{array}{l}\text { Fifth } \\
\text { participant }\end{array}$ & $\begin{array}{l}\text { The first phase has } \\
\text { explained the basic } \\
\text { nature of the study } \\
\text { and the definition of } \\
\text { what architecture }\end{array}$ & $\begin{array}{l}\text { Provide designs bearing } \\
\text { the identity of the region } \\
\text { while simulating the } \\
\text { qualitative shift and } \\
\text { development in the }\end{array}$ & $\begin{array}{l}\text { Trying to reconcile } \\
\text { the desire of the } \\
\text { client and what is } \\
\text { expected of a set of } \\
\text { goals in the design }\end{array}$ & $\begin{array}{l}\text { Adopting } \\
\text { programs to to the } \\
\text { core }\end{array}$ \\
\hline & $\begin{array}{l}\text { The second phase } \\
\text { represented the actual } \\
\text { stage during which } \\
\text { the architectural } \\
\text { profession was dealt } \\
\text { with }\end{array}$ & building materials used. & process & $\begin{array}{l}\text { Pay greater } \\
\text { attention to } \\
\text { building material } \\
\text { and develop its } \\
\text { curriculum to suit } \\
\text { the requirements of }\end{array}$ \\
\hline & $\begin{array}{l}\text { The third stage was a } \\
\text { refinement of the } \\
\text { identity of the student } \\
\text { and determine his } \\
\text { orientation }\end{array}$ & & & imes \\
\hline & $\begin{array}{l}\text { Phase IV represented } \\
\text { a new gateway to the } \\
\text { study of architecture }\end{array}$ & $\begin{array}{l}\text { To submit design } \\
\text { proposals to a number of } \\
\text { areas that represent key }\end{array}$ & & \\
\hline & $\begin{array}{l}\text { Phase } \mathrm{V} \text { was } \mathrm{a} \\
\text { process }\end{array}$ & figures in the governorate. & & \\
\hline
\end{tabular}




\begin{tabular}{|c|c|c|c|c|}
\hline & $\begin{array}{l}\text { information and } \\
\text { knowledge gained }\end{array}$ & & & \\
\hline \multirow[t]{4}{*}{$\begin{array}{l}\text { Sixth } \\
\text { participant }\end{array}$} & $\begin{array}{l}\text { Drawing is a handicap } \\
\text { for those who did not } \\
\text { possess talent }\end{array}$ & \multirow[t]{4}{*}{$\begin{array}{l}\text { Make future projects } \\
\text { more convenient }\end{array}$} & \multirow{4}{*}{$\begin{array}{ll}\text { Continuing } & \\
\text { education } & \text { for } \\
\text { architecture } & \\
\text { profession } & \end{array}$} & $\begin{array}{l}\text { Students are taken } \\
\text { from the first stage } \\
\text { to the site }\end{array}$ \\
\hline & $\begin{array}{l}\text { I did not understand } \\
\text { what architecture in } \\
\text { the first stage }\end{array}$ & & & $\begin{array}{l}\text { Focus on graphics, } \\
\text { building materials } \\
\text { and software }\end{array}$ \\
\hline & $\begin{array}{l}\text { In the third stage I } \\
\text { began my } \\
\text { understanding of the } \\
\text { architectural } \\
\text { profession }\end{array}$ & & & \multirow[t]{2}{*}{$\begin{array}{l}\text { 3Any student } \\
\text { knows the strengths } \\
\text { and weaknesses of } \\
\text { a child }\end{array}$} \\
\hline & $\begin{array}{l}\text { No new information } \\
\text { has been added to my } \\
\text { fifth phase }\end{array}$ & & & \\
\hline
\end{tabular}

\section{Conclusions on the results of the currere approach to the development of the academic curriculum}

\section{8-1 Regressive moment}

1- Dedication of a large amount of time to complete the curriculum of the architectural course, such as the number of hours devoted to this subject within the curriculum, as well as the number of hours spent by the student outside the official working hours, as indicated by the participants.

2- Devoting a time to the formal aspects of the designs much more than the time devoted to study the nature of events and jobs in those projects.

3- The architectural academic study was characterized as indicated by the participants of the vocabulary such as architecture, environment, lighting, acoustics and building systems by superficiality and simplicity.

4- The participants pointed out the ambiguity about the architecture of the first stage and the fact that they began to understand architecture as a profession from the third stage and others in the fourth stage of the study of the architectural academic study.

\section{8-2 Progressive Moment}

1- Participants stressed the importance of awareness and depth in studying the technological potential in design and construction.

2- Participants pointed to the need to be aware of the inputs of the concept of competition in architecture and at all levels of design, operational, technical, consulting, etc.

3- Awareness of the problems of housing and urban environments.

4- Emphasize that the BIM system in the five grades as the most black and important practices.

\section{8-3 Analytical Moment}

1- Emphasize the need to be a graduate student in accordance with the requirements of the reality of the practice of technological aspects and construction or planning and skill of communication with customers and also mechanisms of integration with other engineering specialties.

2- Request for the adoption of mechanisms designed to produce designs for houses or commercial buildings to be environmentally friendly (BIOFILIC DESING).

3- The need to examine the site work before and during the process of construction of various projects.

\section{8-4 Synthetically Moment}

1- Participants pointed to the need to highlight disciplines in the architectural study in view of the progress in all areas related to the design of buildings. 
2- Adoption of modern and specialized software because of its importance in achieving accurate results and direct and real.

3- Emphasize the important role that lighting receives as the element that distinguishes the internal and external spaces - at night.

4- Developing the mechanisms of critical thinking among students and different stages of the study in order to achieve the goal of the classroom and the least time and effort.

\section{$\underline{\text { Recommendations }}$}

1- To review the architectural academic program of the departments of architecture in local universities in terms of compatibility with the requirements of the local and global architectural labor market.

2- To emphasis on the relationship between the requirements of the labor market and the qualifications of the outcomes of the academic program as a prescription for the benefit of this academic product. Graduates or engineers are effective in providing the society with the potential to improve the reality through their integration with the requirements of the labor market.

3- To review some of the vocabulary of the premises and learning outcomes as representing the inputs of the academic program in line with the scientific development, especially in the technological aspect in all aspects of public life.

4- To promote an important set of skills that is the ability to analyze and activate the skills of critical thinking which in turn may result in reducing the unnecessary content of the course.

\section{$\underline{\text { References }}$}

[1] Chalabi, Sawsan, "Quality Assurance and Academic Accreditation in Educational Institutions Objectives and Results Procedures", Lebanese Universities League Conference in Cooperation with the National Office of Tempus European Program, 2011, pp. 1-19.

[2] Hamid, Ahmed, "Quality of Architectural Education - Quality Requirements of Learning Outcomes in the Department of Architecture - University of Technology Model", PhD thesis, University of Technology, Baghdad, Iraq, 2017.

[3] Mulla and Marzouk, Hamid and Salah, "The role of the academic program in the development of students' skills applied to a sample of the faculties of management and economics in Iraqi universities", Journal of the Iraqi University, Volume III, No. (38), 2017, pp. 470-508.

[4] Rizko, Nofal, "Explaining the Justifications for Curriculum Development for the Department of Architecture - Nahrain University", Journal of the Union of Arab Universities, No.2, Baghdad, Iraq, 2018.

[5] Rizko, Abdul Wahab, Al-Jamili, Nofal, Khalid and Saad, "Quality Standards for Students' Performance in the Academic Curriculum of the Department of Architecture, Nahrain University", Journal of the Union of Arab Universities, No.2, Baghdad, Iraq, 2019.

[6] Badawi, Manal, "The Relationship of University Architectural Education to Practice the Architectural Profession in Egypt", Master Thesis, Ain Shams University, Egypt, 2009, pp. 138.

[7] Afifi, Areej, "Architectural Education in Palestine", Master Thesis, An-Najah National University, Palestine, 2012, p. 208.

[8] "The Architectural Profession between Academic Reality and Practice: An Analytical Study in the Light of Iraqi Universities in Accordance with Quality Standards", paper presented at the 5th Arab Conference for Quality Assurance of Education held in Tunis, 2013.

[9] Aghab, Omar, "Integration of graduation projects and the labor market in engineering disciplines", 28th Arab Engineering Conference, Muscat, Sultanate of Oman Knowledge, 2018, pp. 88-92.

[10] Aquarius, Assaad, "Proposed Strategy for Harmonizing the Outcome of Higher Education to the Needs of the Labor Market in Palestine", Master's Thesis, Academy of Leadership and Management, Al-Aqsa University, Palestine, 2017. 
[11] Abul-Ela, Mohamed, Souma and Abdel-Fattah, "Building Capacities and Competencies for Graduates of Civil Engineering Departments to Meet Market Needs, Global Competitiveness and Means of Improving Assessment Methods in Light of the Spread of Private Engineering Institutes in the Arab Republic of Egypt", 28th Arab Engineering Conference, Muscat, 2018, pp. 60-64.

[12] Batouil, Rokaya, "Towards a Competency Based Choice for Employment in the Public Service", Journal of the Foundation, Algeria, Issue 4, 2015, pp. 149- 165.

[13] Ahmed, Ahmed Taha, "Biography .. Concept and Development" Magazine Adab Rafidain, No. (59), 2011, pp. 133-149.

[14] Al-Baghdadi, Abdul Majid, "The Art of Biography and its Types in Arabic Literature", Journal of the Arab Section, No. (23), 2016, pp. 190-208.

[15] Ibrahim, Shaima, "Patterns of Biography - Study and Analysis" Journal of Kura Studies, Volume I, No. (29), 2013, pp. 77-90.

[16] Fizi, Dalal, "Techniques of Narrative in Maqamat Badi'zaman Al-Hamzani, An Analytical and Descriptive Study", Master Thesis, Faculty of Education, Al-Arabi University, Ben-Mehdi, Umm AlBouaqi, Algeria, 2011, p. 208.

[17] Kaun, Y. and Glor, M. 'Currere' to the rescue? Teachers as 'amateur intellectuals' in a knowledge Society" Journal of the Canadian Association for Curriculum Studies, Vol. 4 (2), 2006, PP:101-122.

[18] Thompson, M. C. "Currere, Illnes, and Motherhood: A Dwelling Place for Examining The Self", PhD. Boise Georgia Southern University ,2011, pp: 276.

[19] Pinar, F. W. "THE METHOD OF CURRERE",Paper presented at the annual meeting of the American Research Association, Washington D.C ,1975.

[20] Pinar, W.F. "What is curriculum theory?" This edition published in the Taylor \& Francis eLibrar,2004,pp:316.

[21] Rotas, N. "Bodied Curriculum: A Rhizomean Landscape of Possibility Ossibility", PhD. University of Toronto ,2012, pp: 95.

[22] Stoddart, R. A." Currere As A method for Ctitical Eflection in the Profession of Academic Librarianship.” PhD. Boise State University,2015,pp: 157.

[23] Halvorson, M. A. " Curriculum Design as Being-in-the-World of Study and Teaching: An Autobiographical Re-conceptualization”, PhD.Simon Fraser Uniersity ,2015,pp: 216.

[24] B. Durakovic, "Design for Additive Manufacturing: Benefits, Trends and Challenges", Periodicals of Engineering and Natural Sciences (PEN), vol. 6, pp. 179-191, 2018.

[25] B. Durakovic, Demir, R., Abat, K., and Emek, C., "Lean Manufacturing: Trends and Implementation Issues", Periodical of Engineering and Natural Sciences, vol. 6, no. 1, pp. 130-143, 2018. 